\title{
O discurso candidiano na amplificação de Clarice Lispector
}

\section{Bruna Camargo Correa}

Graduanda em Letras pela Universidade Federal de São Paulo, Brasil

Bolsista de Iniciação Científica - Fundação de Amparo à Pesquisa do Estado de São Paulo (FAPESP) https://orcid.org/0000-0002-8010-084X

Resumo: A crítica literária é um discurso persuasivo que visa louvar ou censurar, assumindo, portanto, relevância para com o sucesso (ou não) de novos escritores na literatura prestigiada. Com base nisso, este texto considera como objeto de análise a crítica literária "Perto do coração selvagem", escrita por Antonio Candido e publicada em 1944, no jornal Folha da Manhã, sobre a estreia literária de Lispector. O objetivo principal é mostrar os recursos retóricos mobilizados para amplificar o caráter virtuoso de Clarice Lispector. Entende-se que compreender a persuasão da crítica literária é fundamental para formação do leitor, já que tal discurso tem o poder de conduzir o leitor à obra. O estudo fundamentase nos pressupostos teóricos da Retórica (ARISTÓTELES, 2015) e da Nova Retórica (PERELMAN; OLBRECHTS-TYTECA, 2014; MEYER, 2007; EGGS, 2008; FERREIRA, 2010; FIORIN, 2015; TRINGALI, 2014), com ênfase no gênero epidítico.

Palavras-chave: Crítica literária. Discurso epidítico. Clarice Lispector. Antonio Candido.

Abstract: The literary criticism is a persuasive discourse that aims to praise or censor, thus assuming relevance to the success (or not) of new writers in prestigious literature. Based on this, this text considers as an object of analysis the literary criticism "Perto do coração selvagem," written by Antonio Candido and published in 1944, in the newspaper Folha da Manhã, about Lispector's literary debut. The main objective is to show the rhetorical resources mobilized to amplify the virtuous character of Clarice Lispector. It is understood that understanding the persuasion of literary criticism is fundamental to the formation of the reader, since such discourse has the power to lead the reader from critical discourse to book. The study is based on the theoretical assumptions of Rhetoric (ARISTÓTELES, 2015) and New Rhetoric (PERELMAN; OLBRECHTS-TYTECA, 2014; MEYER, 2007; EGGS, 2008; FERREIRA, 2010; FIORIN, 2015; TRINGALI, 2014), with emphasis on the epiditic gender.

Keywords: Literary criticism. Epiditic discourse. Clarice Lispector. Antonio Candido. 


\title{
Considerações iniciais
}

O discurso crítico-literário consiste em um objeto de educação e de formação literária pouco produzido e veiculado na atualidade. Tal discurso tinha, em especial na década de 40, um papel social relevante, pois, quando veiculado nos jornais impressos, dispunha do poder de conduzir o leitor do jornal, que se deparava com a crítica, a ler uma determinada obra literária. Segundo Candido (2004, p. 175)

\begin{abstract}
nas nossas sociedades a literatura tem sido um instrumento poderoso de instrução e educação, entrando nos currículos, sendo proposta a cada um como equipamento intelectual e afetivo [...]. A literatura confirma e nega, propõe e denuncia, apóia e combate, fornecendo a possibilidade de vivermos dialeticamente os problemas.
\end{abstract}

Com base no pensamento de Antonio Candido (2004), pode-se dizer que o caráter persuasivo da crítica literária, que requer práticas retóricas, unido ao caráter social e reflexivo da Literatura tornam o discurso do crítico um instrumento de letramento literário, o qual induz o leitor a refletir e formar um pensamento crítico, prática escassa na educação moderna. É em razão de seu poder persuasivo que a crítica literária se configura como um discurso de ordem epidítica, gênero retórico que objetiva louvar ou censurar, no caso em foco, uma obra e seu autor.

Baseado nessas ponderações, este artigo objetiva analisar como os expedientes retóricos auxiliam na amplificação do caráter notável de Clarice Lispector. Tem-se como hipótese central que é possível encontrar recursos retóricos (como figuras, lugares, argumentos e seleção lexical) de amplificação que permitem a constituição de um discurso laudatório a respeito da autora. Justifica-se este estudo em razão da escassez de trabalhos que investigam a construção persuasiva do discurso críticoliterário.

O objeto em análise é o artigo "Perto do coração selvagem", escrito pelo crítico literário Antonio Candido e publicado em 16 de julho de 1944 na seção de rodapé "Notas de críticas literárias", do jornal Folha da Manhã. Na crítica, Candido versa positivamente sobre o romance de estreia - Perto do coração selvagem, publicado em dezembro de 1943 - da escritora modernista Clarice Lispector.

No mais, o artigo está organizado da seguinte forma: primeiro apresenta-se a discussão teórica dos gêneros retóricos, com foco no gênero epidítico. Em seguida, expõe-se uma breve contextualização do crítico Antonio Candido e da escritora Clarice Lispector. Posteriormente, mostram-se a análise dos dados e por fim os resultados obtidos nas considerações finais. 


\section{O gênero epidítico: conceito-chave}

A Retórica, segundo Aristóteles (2015, p. 62), configura-se na "capacidade de descobrir o que é adequado a cada caso com o fim de persuadir", de maneira que o discurso é a principal fonte de persuasão. Para o pensador, o discurso compreende três elementos: o orador, que se refere a quem fala; o assunto, que diz respeito ao que se fala; e o ouvinte, que corresponde ao auditório do orador, isto é, a quem se fala. É o ouvinte que representa a finalidade do discurso, visto que o orador molda o assunto com base em seu ouvinte/auditório, com intencionalidade persuasiva. Para tanto é preciso que o ouvinte assuma a função de espectador ou de juiz, de forma que Aristóteles (2015), em reflexão sobre a função do auditório (ouvinte), propõe três gêneros retóricos: o deliberativo, o judiciário e o epidítico (ou laudatório).

O gênero deliberativo assume a função de aconselhar ou dissuadir, refletindo sobre uma ação futura em razão do que é conveniente ou prejudicial, de modo que o auditório atua como assembleia. O gênero judiciário admite a função de acusar ou defender, ponderando sobre uma causa passada, justa ou injusta, de forma que o auditório atua como juiz. Já o epidítico objetiva louvar ou censurar, analisando, em especial, na perspectiva do presente, o que é agradável/belo ou desagradável/feio, de maneira que o auditório atua como espectador (cf. ARISTÓTELES, 2015). Além das características apresentadas para cada gênero, é relevante ressaltar o tipo de argumentação produzida por cada um deles. Reboul (2004, p. 46) resume:

O judiciário, que dispõe de leis e se dirige a um auditório especializado, utiliza de preferência raciocínios silogísticos (entimemas), próprios a esclarecer a causa dos atos. O deliberativo, dirigindo-se a um público mais móvel e menos culto, prefere argumentar pelo exemplo, que, aliás, permite conjecturar o futuro a partir dos fatos passados [...]. Quanto ao epidítico, recorre sobretudo à amplificação, pois os fatos são conhecidos pelo público, e cumpre ao orador dar-Ihes valor, mostrando sua importância e nobreza.

Segundo Mosca (2001, p. 32), "embora esses gêneros sejam bem delineados, dentro da mesma argumentação podem ocorrer traços dos três tipos de discurso, numa relação de dominância e não de exclusão".

Meyer (2007, p. 28), ao comparar sinteticamente a distinção dos gêneros retóricos e dos gêneros literários, afirma que o literário "em retórica, trata-se do gênero epidítico, centrado no estilo atraente e agradável, em que o auditório desempenha um papel preciso, pelo fato de comandar o louvor ou a aclamação ou a censura". A partir desse pensamento, pode-se dizer que a distância entre o orador e o auditório, no 
gênero epidítico, é negociada mais facilmente, afinal “porque visa anulá-la, cumpre sua função com perfeição" (MEYER, 2007, p. 30).

É importante ressaltar que Aristóteles (2015) também apresenta três provas de persuasão, quais sejam o ethos ${ }^{1}$ (caráter moral, imagem, personalidade do orador), o pathos (disposição do ouvinte; paixões mobilizadas pelo orador no auditório) e o logos (discurso propriamente dito). Além disso, o pensador revela três qualidades imprescindíveis para a constituição do ethos, quais sejam: a phrónesis (prudência), a areté (virtude) e a eúnoia (benevolência), que correspondem, na devida ordem, ao orador ser sensato, sincero e simpático (cf. ARISTÓTELES, 2015).

Os precursores da Nova Retórica, Perelman e Olbrechts-Tyteca (2014, p. 26), que se mostram interessados especialmente na prova do logos, apresentam uma nova visão: a adaptação do discurso do orador conforme o seu auditório, objetivando a adesão dos argumentos. Assim, o ethos será constituído de acordo com o gênero em que o discurso está inserido, no caso do epidítico, é preciso dispor de um ethos com autoridade no assunto tratado, de modo a apresentar habilidades linguísticas para adaptar o discurso ao auditório e garantir o êxito persuasivo. Isso posto, é essencial que o orador construa uma imagem de si manifestando credibilidade em seu discurso, a fim de aproximar o auditório da ação pretendida. De acordo com Meyer (2007, p. 129), "é com base no ethos que se diminui a distância, um processo que precedentemente denominámos argumentação" ou "criação de identidade entre parceiros" sobre uma questão".

À vista de a crítica literária ser interpretada como um discurso persuasivo, podemos classificá-la como de ordem epidítica, dado que sua funcionalidade retórica em relação ao discurso é louvar ou censurar um autor e sua obra, assim, admite um caráter estético e avaliativo. Segundo Perelman e Olbrechts-Tyteca (2014, p. 57), é na ordem epidítica que “o orador se faz educador". A partir desse pensamento, Reboul (2004, p. 46) complementa e ressalta que o gênero epidítico "é essencialmente pedagógico", já que "orienta escolhas futuras”, isto é, condiciona o leitor para a ação baseada no parecer do crítico. Tringali (2014, p. 71) também defende o papel educativo do gênero epidítico, afirmando que "ele desperta a reflexão crítica, forma a opinião e dispõe remotamente para a ação”.

\footnotetext{
${ }^{1}$ Neste estudo a definição que mais se adapta ao objeto de análise é a de Ferreira (2010, p. 90), que entende o ethos como "a imagem que o orador constrói de si e dos outros no interior do discurso", assim, Antonio Candido constrói não somente uma imagem de si mesmo, como também da escritora Clarice Lispector, no interior do discurso críticoliterário.
} 
Dentre essas ponderações, convém ressaltar que a crítica literária foi, predominantemente, veiculada em jornais, ou seja, apesar da leitura na década de 40 ser um privilégio, muitos não tinham a intenção de se deparar com um discurso críticoliterário, de modo que ao encontrá-lo (comumente na parte inferior da página do jornal, conhecida por folhetim) constituído de boa argumentação, o leitor era direcionado à obra ou ao menos despertava-lhe interesse. Coligando essa consideração à Retórica, Perelman e Olbrechts-Tyteca (2014, p. 50) reiteram:

uma argumentação eficaz é a que consegue aumentar essa intensidade de adesão, de forma que desencadeie nos ouvintes a ação pretendida (ação positiva ou abstenção) ou, pelo menos, crie neles uma disposição para a ação, que se manifestará no momento oportuno.

Ainda sobre a ordem epidítica da crítica literária, Tringali (1988, p. 53) reafirma o enquadramento desta como um discurso epidítico: "Dos três gêneros oratórios, o laudatório é o que mais afinidades mantém com a literatura, funciona mesmo, por assim dizer, como ponte de passagem entre a literatura e a Retórica".

$\mathrm{Na}$ crítica literária em questão, manifesta-se o elogio. Sobre isso, Aristóteles (2015, p. 89) reflete que "o elogio é um discurso que manifesta a grandeza de uma virtude", assim

a amplificação enquadra-se logicamente nas formas de elogio, pois consiste em superioridade, e a superioridade é uma das coisas belas. Pelo que, se não é possível comparar alguém com pessoas de renome, é pelo menos necessário compará-lo com as outras pessoas, visto que a superioridade parece revelar a virtude (ARISTÓTELES, 2015, p. 90).

A figura da amplificação pode aparecer num discurso tanto de forma positiva (como ocorre no caso em questão) quanto de forma negativa, ressaltando algo ou alguém. Desse modo, a amplificação configura-se como uma figura de presença que, segundo Perelman e Olbrechts-Tyteca (2014, p. 197), tem "por efeito tornar presente na consciência o objeto do discurso", assim, muitas vezes acompanha a figura da repetição, a fim de valorizar o que se diz sobre determinado referente. Nesse sentido, observa-se a amplificação no âmbito do elogio.

Ainda assim, sabe-se que a ciência linguística declara que todo discurso presume uma resposta, entretanto, quando o orador profere tal elogio, o auditório não o responde prontamente, mas isso não significa que não exista uma resposta. Segundo Tringali (2014), diferente dos outros dois gêneros, o epidítico não exige uma resposta com urgência, ainda que a resposta para esse discurso não seja irrelevante. É o que 
ocorre, muitas vezes, na crítica literária, a qual se revela como de gênero epidítico por meio de recursos retóricos.

\section{De Antonio Candido à Clarice Lispector}

Antonio Candido de Mello e Souza (1918-2017) foi um crítico e intelectual brasileiro, formado em Ciências Sociais pela Faculdade de Filosofia ${ }^{2}$ em 1942, que se tornou uma referência acadêmica e social para com a Literatura nacional. Em decorrência de sua apreciação pela literatura mundial, Candido ingressou no mundo das Letras em 1958, onde se tornou professor, pensador e escritor, de maneira que lapidou um extenso legado frente aos estudos literários. Pode-se dizer que Candido iniciou sua carreira como crítico "sem intenção": foi convidado, mesmo sem competências linguísticas na área, para exercer a função de crítico no grupo Clima ${ }^{3}$ (cf. RODRIGUES, 2018).

Como consequência de sua formação, o crítico costumava observar a obra não somente pelo viés literário como também pelo viés social, o que o levou a ser classificado, muitas vezes, como "crítico sociólogo", entretanto Candido afirma que, diferente disso, foi um crítico ideológico e o que o interessava era a crítica funcional, isto é, o papel da obra na sociedade (cf. RODRIGUES, 2018, p. 256). Além disso, o crítico parece não simpatizar com o enquadramento da crítica em um gênero, entende a mesma como um gênero auxiliar, lateral e dependente (cf. PINTO, 2010).

Antonio Candido se destacou como crítico principiante no grupo Clima e foi convidado, em 1943, a assumir o cargo de crítico titular do jornal Folha da Manhã, suporte em que estreou profissionalmente e atingiu sua fama como um crítico literário renomado. Foi no então jornal, ainda novato, que reconheceu e atribuiu seu aval crítico a escritores ainda em debute, como no caso de Clarice Lispector.

Clarice Lispector (do original Haia Pinkusovna Lispektor ${ }^{4}$, 1920-1977), embora recusasse o título de escritora de prestígio - pois enxergava o labor da escrita não como um trabalho, mas sim como um prazer, sem compromissos -, é considerada destaque do Movimento Modernista brasileiro. Segundo Alfredo Bosi (2015, p. 323) o

\footnotetext{
2 Atual Universidade de São Paulo (USP).

${ }^{3}$ Revista fundada por universitários da USP, em 1939, com objetivo de escrever críticas culturais (cinema, literatura e teatro).

${ }^{4}$ Clarice Lispector, apesar de reconhecida como escritora brasileira, nasceu na aldeia de Tchetchelnik na região de Vínnitsia, na Ucrânia.
} 
modernismo é um movimento que lançou "estéticas originais em relação às nossas últimas correntes literárias", assim,

O que a crítica nacional chama de Modernismo está condicionado por um acontecimento, isto é, por algo datado, público e clamoroso, que se impôs à atenção da nossa inteligência como um divisor de águas: A Semana de Arte Moderna, realizada em fevereiro de 1922, na cidade de São Paulo.

Apesar de já definida como hermética, foi reconhecida oficialmente em 11 de agosto de 2020 como patrona da Literatura do estado de Pernambuco, terra onde viveu a escritora (que se declarava pernambucana) e sua família após se refugiarem para o Brasil em decorrência da Revolução Russa de 1917. Ainda que estrangeira (e de tentar escrever em outras línguas, como ela mesma relata), Clarice afirma que pensa e sente em português e que somente essa língua penosa e terrível a satisfaria (cf. BORELLI, 1981; GOTLIB, 2009; ROSA, 2020).

Lispector, que trabalhou como professora particular e como repórter, começou as atividades na literatura em 1931, quando com a ajuda de sua irmã enviou alguns contos para a seção infantil do Diário de Pernambuco, os quais não foram publicados. Nove anos depois, publica seu primeiro texto, intitulado "O triunfo" no periódico Pan, no Rio de Janeiro. Entretanto, o debute da escritora é em 1943, ano de publicação de seu primeiro romance nomeado Perto do coração selvagem ${ }^{5}$ (1943). No mesmo ano formou-se no curso de Direito pela Universidade do Brasil (atual Universidade Federal do Rio de Janeiro - UFRJ). Suas grandes obras são: A hora da estrela (1977), A paixão segundo G.H (1964), Laços de família (1960) e Perto do coração selvagem (1943). Clarice Lispector, ainda que rara estreante, inovou a estética da prosa brasileira com sua ousadia e originalidade (cf. GOTLIB, 2009; CORREA, 20206).

\section{A crítica literária como discurso epidítico de louvor}

Com o intuito de demonstrar como a crítica literária assume caráter epidítico, analisar-se-ão os mecanismos retóricos utilizados na produção do elogio no interior da crítica "Perto do coração selvagem", publicada em 16 de julho 1944, no rodapé do jornal Folha da Manhã, pelo crítico-orador Antonio Candido, sobre o romance de estreia

\footnotetext{
${ }^{5}$ A obra foi publicada em dezembro de 1943 e logo em seguida foi premiada como melhor romance de estreia pela Fundação Graça Aranha (cf. GOTLIB, 2009).

6 Artigo decorrente deste estudo, onde analisamos os ethé de Candido e Lispector, disponível em: http://www.revistas.unilab.edu.br/index.php/mandinga/article/view/429.
} 
literária da escritora modernista Clarice Lispector. A título de contextualização, o objeto em análise se configura em um artigo de dez parágrafos críticos, os quais versam sobre a estética da autora, o gênero da obra, os elementos narrativos, uma síntese do romance e por fim o aval crítico.

\subsection{A autoridade do crítico na tese de adesão inicial}

Antes de examinar os dados que constituem o elogio, é válido explorar como Antonio Candido introduz o discurso crítico-literário. Tal introdução se faz relevante pois a apresentação inicial de um discurso é capaz de despertar a atenção do leitor para a obra em questão. Dessa forma, Antonio Candido começa sua crítica tratando sobre a situação literária da época e, à vista disso, estabelece uma relação que é o ponto de partida em direção ao aval crítico. Na Retórica, essa ação introdutória é chamada de tese de adesão inicial ou premissa da argumentação e se configura numa presunção preparatória, sendo o primeiro passo para a persuasão. Tal premissa objetiva fazer com que o auditório esteja de acordo com ela, assim, o caminho para a tese principal ganha estabilidade e é instituído um acordo entre o orador e o auditório (cf. ABREU, 2009; PERELMAN, OLBRECHTS-TYTECA, 2014).

O crítico inicia o primeiro parágrafo com a seguinte citação: "Todos os homens que estão fazendo um grande nome em arte... fazem-no porque evitam o inesperado; porque se especializam em pôr as suas obras no mesmo encaixe que outras, de modo que o público sabe imediatamente onde tem o nariz". Tal citação faz alusão a um crítico de arte e soa como um conselho: deve-se abandonar a rotina que visa o sucesso e apostar no talento, na ousadia da inovação. Candido encerra o discurso com outra citação ou com as "sábias palavras", como ele mesmo diz, do crítico aludido: "aconselhando-o a abandonar as suas veleidades pessoais e entrar na rotina comum, acrescentou estas sabias palavras: 'e isto é tanto mais fácil para o senhor quando não há uma originalidade muito acentuada no seu estilo”.

Dessa forma, em sua tese de adesão inicial, Antonio Candido procura relacionar a citação do crítico de arte à situação da Literatura brasileira da época, a qual, para ele, encontrava-se em cenário rotineiro, sem o prazer do novo. Contudo, considerando que o crítico se vale de duas citações ${ }^{7}$ e uma alusão ${ }^{8}$ para encaminhar a tese principal

\footnotetext{
7 Segundo Perelman e Olbrechts-Tyteca (2014, p. 201), a citação objetiva "apoiar o que se diz com o peso de uma autoridade".

8 "referência a um fato, a uma pessoa real ou fictícia, conhecida do interlocutor" (ABREU, 2009, p. 139).
} 
(inovação proposta por Clarice Lispector), é possível observar dois tipos de técnicas argumentativas que corroboram para uma possível aceitação do auditório à tese.

A primeira é a argumentação pela analogia. Segundo Fiorin (2019, p. 64), "a analogia é o raciocínio em que de uma proposição particular se conclui uma proposição particular somente pela semelhança dos casos referidos”. Nesse caso, ao fazer uso da alusão, Candido busca estabelecer uma comparação da tese de adesão inicial com um fato que tenha relação com a tese principal. Desse modo, Candido compara a fala do crítico de arte à sua visão da situação literária nacional. O segundo argumento observado é o argumento de autoridade, caracterizado pela citação. Como registra Ferreira (2010, p. 128), “a citação funciona como um argumento de autoridade”. À vista disso, o argumento de autoridade se refere ao caráter, à imagem, isto é, ao ethos da pessoa citada que valida as intenções do discurso (cf. FERREIRA, 2010, p. 166).

Contudo, considerando que Antonio Candido se vale de citações e de analogia para iniciar o seu discurso, em caráter de aceitação ao que disse o crítico aludido, mostra-se como um crítico bem informado e com uma opinião próxima a de outros profissionais da área. Assim, Candido se apresenta como um crítico-orador competente para tratar do assunto.

\title{
3.2 A amplificação de Clarice Lispector: primeiros elogios
}

Após se apresentar como um orador que possui autoridade para tratar da estreia literária de Clarice Lispector, Antonio Candido introduz a tão jovem estreante em seu discurso, deslocando-a da literatura corriqueira e alocando-a na escrita rara:

\begin{abstract}
Assim, na bitola comum da arte, o melhor do artista seria sofrear os seus ímpetos originais e procurar uma excelência relativa dentro de uma certa rotina, mediana mas honesta e sólida. [...] No entanto mesmo na craveira ordinária dos talentos, há quem procure uma via mais acentuadamente sua, preferindo o risco da aposta à comodidade do ramerrão. É o caso da sra. Clarice Lispector, que nos deu no fim do ano passado um romance de tom mais ou menos raro na nossa literatura moderna, já qualificada de "ingenuamente naturalista" por um crítico de valor, numa frase que me parece exagerada. O que se poderia dizer, com maior justeza, é que os escritores brasileiros se contentam no geral com processos já usados, apenas um ou outro arriscando em tentativas mais ousadas. ${ }^{9}$
\end{abstract}

\footnotetext{
${ }^{9}$ A transcrição da crítica literária completa pode ser encontrada no artigo "A retórica de Candido na construção das imagens de si e de Clarice". Link para visualização na íntegra: http://www.revistas.unilab.edu.br/index.php/mandinga/article/view/429.
} 
Na primeira menção que faz à escritora, é possível observar recursos retóricos que a amplificam. É o caso das figuras conhecidas como metáfora, alusão e eufemismo; da argumentação pela regra de justiça; do lugar de qualidade e da seleção lexical. Analisar-se-ão, portanto, os recursos retóricos mobilizados no trecho citado que são capazes de amplificar a autora.

O crítico-orador introduz duas metáforas que se complementam. Essa figura é definida por Fiorin (2019, p. 34) como "o tropo em que se estabelece uma compatibilidade predicativa por similaridade, restringindo a extensão sêmica dos elementos coexistentes e aumentando sua tonicidade". A primeira delas pode ser vista em "na bitola ${ }^{10}$ comum da arte, o melhor para o artista seria sofrear os seus ímpetos originais e procurar uma excelência relativa dentro de uma certa rotina, mediana mas honesta e sólida", uma vez que se observa uma seleção lexical que remete a um percurso ou movimento (bitola consiste na 'largura entre dois trilhos', sofrear é o 'ato de mudar a marcha'). Em continuação, apresenta uma segunda metáfora em "mesmo na craveira ordinária dos talentos, há quem procure uma via mais acentuadamente sua [...]". Assim, ao utilizar o termo "via" nos dá a ideia de "caminho", reforçando uma metáfora de percurso, a qual objetiva "associar a resolução de problemas a uma jornada" (ABREU, 2009, p. 120). O problema em questão é a comodidade em que se encontra a literatura brasileira. E uma possível solução a esse problema seria a inovação lispectoriana à luz do momento.

É a partir da metáfora de percurso que Candido chega ao caso da escritora: "[...] há quem procure uma via mais acentuadamente sua, preferindo o risco da aposta à comodidade do ramerrão. É o caso da sra. Clarice Lispector [...]”. Desse modo, é possível observar que todo o discurso metafórico, até então, é construído em forma de elogio, devido à ousadia da escritora ao apostar em uma nova estética, fugindo dos padrões literários da época. O elogio metafórico apresenta Lispector como uma escritora original e tal afirmação pode ser confirmada quando o crítico-orador afirma que Clarice apresenta "um romance de tom mais ou menos raro na nossa literatura moderna". O uso do termo "raro" é um elogio por si só, entretanto, é acentuado por se classificar como recurso argumentativo, isto é, como lugar de qualidade.

De acordo com Perelman e Olbrechts-Tyteca (2014, p. 101), "o lugar de qualidade redunda na valorização do único", assim, ao classificar o romance como raro, classificase também a escritora como rara. Entretanto, apesar da escolha do termo "raro" para

10 Todos os grifos em negrito são nossos. 
definir o romance, observa-se no contexto o uso da figura do eufemismo ${ }^{11}$ pelo críticoorador, empregada por meio da expressão "mais ou menos", a fim de tornar o elogio ponderado, já que se refere a uma escritora estreante, da qual não se sabe o futuro.

A figura do eufemismo pode ser vista novamente quando Antonio Candido se opõe à afirmação do crítico ao qual alude; dado observado no trecho "já qualificada de "ingenuamente naturalista" por um crítico de valor, numa frase que me parece exagerada. $O$ que se poderia dizer, com maior justeza [...]”. Dessa forma, Candido faz alusão ao dito de um crítico de valor (não identificado pelo orador) e intenta reformular a classificação dada à escritora, entretanto, atua de maneira prudente, com apoio do eufemismo, como é possível verificar nas expressões: "frase que me parece exagerada", em que o crítico se opõe, mas, diminui a intensidade da oposição mediante ao uso do pronome oblíquo átono "me", que reforça um discurso de opinião e; "o que se poderia dizer", na qual se utiliza o modalizador "poderia”, intensificando, mais uma vez, sua opinião. Assim, ao se utilizar do eufemismo, mostra-se ponderado ao contrariar o crítico aludido e reformular o que ele já havia dito sobre a escritora, e se mantém em seu posto profissional, já que também realça sua opinião e seu entusiasmo com o rumo que a Literatura sofreria.

$\mathrm{Na}$ tentativa de reformular o que havia sido dito sobre a autora pelo crítico aludido, Antonio Candido alega em seu discurso que o crítico não foi justo ao qualificar Lispector como "ingenuamente naturalista”. Isso é feito por intermédio do argumento conhecido como regra de justiça, que pode ser observado em "O que se poderia dizer, com maior justeza, é que os escritores brasileiros se contentam em geral com processos já usados, apenas um ou outro arriscando em tentativas mais ousadas". Conforme Perelman e Olbrechts-Tyteca (2014, p. 248), "a regra de justiça requer a aplicação de um tratamento idêntico a seres ou a situações que são integrados numa mesma categoria". No fragmento em questão, esse argumento pode ser identificado pelo termo "justeza", retratado com apoio do adjetivo "maior", o qual revela superioridade. Dessa forma, ao dizer "com maior justeza" intenta ser justo frente ao valor da tão ousada escritora. Entende-se o uso da regra de justiça como recurso de amplificação pelo sentido semântico de superioridade, já que, de acordo com Aristóteles (2015, p. 90), “a amplificação enquadra-se logicamente nas formas de elogio, pois consiste em superioridade, e a superioridade é uma das coisas belas", sendo Clarice Lispector superior àqueles que produziam literatura na época.

11 "é o tropo em que há uma diminuição da intensidade semântica" (FIORIN, 2019, p. 78). 
Os recursos retóricos mobilizados exploram o elogio por meio da amplificação, assim, reforçam o enquadramento da crítica literária como gênero epidítico, já que no discurso em questão, Clarice Lispector é louvada no tempo presente (o qual se refere à década de 40). Assim, a introdução avaliativa do crítico sobre a escritora é capaz de apresentá-la como superior àqueles que produziam literatura na época, dado que retoma o pensamento de Aristóteles (2015), já discutido anteriormente, de que a superioridade é bela, portanto, enaltece. Logo, observam-se os traços do gênero epidítico já no início do discurso.

Contudo, os elogios primordiais redundam, majoritariamente, à inovação literária proposta por Clarice Lispector no modernismo brasileiro, com respaldo na ideia de que a escritora ousou em sua escrita, dando-lhe um caráter raro a ponto de o crítico-orador, ainda que ponderado, adequar a imagem da escritora frente ao seu devido valor. Dessa forma, enaltecendo a escrita rara de Clarice Lispector, Antonio Candido reajusta o lugar da Literatura do corriqueiro para o raro.

\subsection{A amplificação de Clarice Lispector: a estética inovadora}

O reajuste do lugar da Literatura nacional fica cada vez mais evidente no discurso candidiano. Após expressar os primeiros elogios à raridade da autora, que desvia da escrita corriqueira, Antonio Candido começa a tratar do romance em si e o faz de maneira positiva com relação à inovação estética proposta por Clarice Lispector:

Em relação a "Perto do coração selvagem", se deixarmos de lado as possíveis fontes estrangeiras de inspiração, permanece o fato de que, dentro da nossa literatura, é uma performance da melhor qualidade [itálico do crítico]

A autora - ao que parece uma jovem estreante - colocou seriamente o problema do estilo e da expressão. Sobretudo desta. Sentiu que existe uma certa densidade afetiva e intelectual que não é possível exprimir se não procurarmos quebrar os quadros da rotina e criar imagens novas, novos torneios, associações diferentes das comuns e mais fundamente sentidas. [...] Como os outros, ela nada consegue, a não ser esse timbre que revela as obras de exceção e que é a melhor marca do espírito sobre a resistência das coisas.

Nos trechos é possível identificar recursos retóricos como a seleção lexical, os lugares de qualidade e de essência e a figura da antítese. Tais recursos aparecem de forma positiva no discurso e, com isso, ajudam a amplificar Clarice Lispector e, consequentemente, a produzir o elogio que caracteriza o gênero epidítico. 
No decorrer da crítica, Antonio Candido se mostra entusiasmado e simpatiza com a produção da escritora estreante da qual não tinha nenhuma referência: "se deixarmos de lado as possíveis fontes estrangeiras de inspiração, permanece o fato de que, dentro da nossa literatura, é uma performance da melhor qualidade". No trecho apresentado, o entusiasmo do crítico-orador fica evidente quando ele se mostra disposto a ignorar as fontes estrangeiras de inspiração, devido ao romance representar a inovação da estética nacional. Assim, define o romance como "uma performance da melhor qualidade", mobilizando, portanto, o lugar de qualidade. Como já delineado, conforme Perelman e Olbrechts-Tyteca (2014, p. 105), o lugar de qualidade, que representa a valorização do único, pode se manifestar "por oposição ao comum, ao corriqueiro, ao vulgar", como ocorre no caso em análise: a escrita clariceana se opõe à escrita corriqueira. À vista disso, o lugar de qualidade é notado mediante à seleção lexical, isto é, pelo uso do adjetivo "melhor" e do substantivo "qualidade", que enfatizam a singularidade da obra.

Observa-se também, no mesmo trecho, o lugar de essência que, segundo Perelman e Olbrechts-Tyteca (2014, p. 106), concede "um valor superior aos indivíduos enquanto representantes bem caracterizados dessa essência". Assim, ao mencionar que o romance se configura numa "performance da melhor qualidade", entende-se que Perto do coração selvagem (2019) representa uma literatura de prestígio, reservando ao romance a essência da literatura brasileira. Para mais, ao utilizar o adjetivo "melhor" e o substantivo "qualidade" lado a lado para definir a obra, o orador aviva o elogio e amplifica Clarice Lispector como superior à literatura corriqueira.

No que se refere ao estilo e à expressão da jovem estreante, Antonio Candido afirma que ela soube se colocar na escrita de maneira séria e consequentemente rara. Assim, segundo o crítico, a autora "Sentiu que existe uma certa densidade afetiva e intelectual que não é possível exprimir se não procurarmos quebrar os quadros da rotina e criar imagens novas, novos torneios, associações diferentes das comuns e mais fundamente sentidas". Dessarte, Antonio Candido declara que o nível de expressão da escritora não coube no molde habitual. No trecho, observa-se uma seleção lexical que remete à inovação: "quebrar", "rotina”, "novas", "diferente” e "comum". A escolha dos termos reafirma a estética da escritora como de melhor qualidade, de modo que distancia Lispector de uma literatura padronizada e a aproxima da literatura original.

Outro trecho que reafirma a estética inovadora de Clarice Lispector é "Como os outros, ela nada consegue, a não ser esse timbre que revela as obras de exceção e que é a melhor marca do espírito sobre a resistência das coisas". Nessa passagem é 
possível identificar a figura da antítese, que, conforme Fiorin (2019, p. 152), enfatiza o que se diz mediante a contradição. Assim, a antítese aparece quando o orador diz que "ela nada consegue", mas se contradiz ao completar: "a não ser esse timbre que revela as obras de exceção". Desse modo, o crítico-orador se contradiz para dar ênfase em "obras de exceção", que é como o romance é avaliado e apreciado por Antonio Candido. No mesmo trecho, é possível verificar o lugar de essência na construção "melhor marca do espírito sobre a resistência das coisas", em que o uso do adjetivo "melhor", uma vez mais, valoriza Clarice Lispector como uma escritora superior à luz do momento.

O elogio e a superioridade são ainda mais ressaltados quando o crítico trata da estética da autora, já que é o caráter estético que permite uma avaliação louvável. Por ser de ordem epidítica, a crítica literária fica mais evidente no laudo estético, principalmente, porque é com o interior da obra que o leitor lidará. À vista disso, retoma-se o pensamento de Reboul (2004, p. 46) que afirma que o gênero epidítico “orienta escolhas futuras". Assim, a avaliação valorosa que o crítico atribui à escritora permite que o leitor do jornal seja conduzido futuramente ao romance.

Isso posto, a estética da escritora é claramente inovadora aos olhos de Antonio Candido, de modo que o crítico está disposto a desconsiderar as fontes estrangeiras de inspiração, já que para ele o romance é uma obra de exceção frente às produções do momento. Assim, observam-se traços que introduzem o aval crítico, como a amplificação pelo elogio que é recorrente no discurso crítico-literário, visto que a estética clariceana variou o molde literário nacional.

\subsection{A amplificação de Clarice Lispector: em foco o aval crítico}

No que tange o aval crítico, ainda que esse já tenha ficado claro devido à gama de elogios tecidos por Antonio Candido à estreante Clarice Lispector, o crítico finda o discurso com deleite e profissionalismo:

De tal estofo são feitas as grandes obras. O livro da sra. Clarice Lispector não o é, certamente. Todavia, poucos como ele, têm, ultimamente, permitido respirar numa atmosfera que se aproxima da grandeza. E isto, em grande parte, porque a sua autora soube criar o estilo conveniente para o que tinha a dizer. Soube transformar em valores as palavras, nas quais muitos não veem mais do que sons ou sinais. A intensidade com que soube escrever e a rara capacidade da vida interior poderão fazer desta jovem escritora um dos valores mais sólidos e, sobretudo, mais originais da nossa literatura, porque esta primeira experiência já é uma nobre realização. 
O crítico-orador inicia o fragmento afirmando que o romance de Lispector não é uma grande obra, isto é, não poderia ser considerado um cânone literário, entretanto reconhece o valor de Perto do coração selvagem (2019) ao afirmar que "se aproxima da grandeza”. Nota-se, no aval candidiano, uma seleção lexical que reafirma sua apreciação ao feito de Clarice Lispector: "aproxima”, "grandeza”, "criar o estilo", "intensidade”, "rara capacidade”, “valores", “sólidos”, “originais" e "nobre”. Assim, entende-se que, mesmo que a escritora não tenha produzido um romance que fosse para a estante dos clássicos, ela chegou perto já em sua primeira publicação, o que é admirável para o crítico que estava incomodado com o padrão literário da década de 1940.

Tal admiração pela produção lispectoriana permitiu que o crítico enxergasse um futuro para a jovem escritora: "A intensidade com que soube escrever e a rara capacidade da vida interior poderão fazer desta jovem escritora um dos valores mais sólidos e, sobretudo, mais originais da nossa literatura, porque esta primeira experiência já é uma nobre realização". Verifica-se o uso do futuro do presente do indicativo do verbo "poder" (poderão) e, em seguida, o uso do verbo no infinitivo "fazer", que forma a expressão "poderão fazer", a qual demonstra que o crítico percebeu um sucesso futuro da escritora no interior da literatura nacional, já que o primeiro romance foi "uma nobre realização".

No que diz respeito ao aval crítico, observa-se que o gênero epidítico é o que mais se enquadra na crítica literária, dado que a presença do elogio como amplificação da autora é permanente no discurso crítico. Dessa forma, ao louvar Clarice Lispector, o crítico mostra que a resposta ao discurso não tem necessidade imediata, posto que o leitor deve ler o romance e tirar suas próprias conclusões. Conforme Tringali (2014, p. 71), o gênero epidítico permite reflexão crítica, forma opiniões e "dispõe remotamente para ação”. Nesse sentido, ao ler a crítica em questão, o leitor do jornal reflete e, ao despertar-lhe interesse, lê o romance para tirar suas próprias conclusões.

Contudo, Antonio Candido não somente aprova o romance, mas também o avalia como raro. Já com relação a Clarice Lispector, ele mostra que a autora é capaz de se enquadrar como um dos valores mais sólidos da literatura brasileira. Dessa forma, o crítico não errou ao apostar na tão jovem estreante: Clarice Lispector é considerada uma das mais grandiosas escritoras do modernismo brasileiro, sendo reconhecida mundialmente. Certamente a escolha das palavras para se referir à escritora amplificam de maneira positiva a imagem de Lispector, pois na época pouco se tinha referências ou informações a respeito de sua pessoa e seus escritos. 


\section{Considerações finais}

Na crítica "Perto do coração selvagem", publicada em julho de 1944, no jornal Folha da Manhã, o crítico literário Antonio Candido cede seu aval crítico a Clarice Lispector, que publicou seu primeiro romance - Perto do coração selvagem - em dezembro de 1943. Dado isso, o aval crítico é cedido mediante a uma gama de elogios que amplificam o caráter da escritora e a nomeia como quem inovou a estética brasileira à luz do momento. Tais elogios que amplificam Lispector permitem a constituição de um discurso epidítico, o qual visa louvar ou censurar uma obra e seu autor.

As análises dos trechos mostraram, primeiramente, que o crítico possui autoridade para tratar da estreia literária de Clarice Lispector, mediante sua tese de adesão inicial, que versa sobre a situação corriqueira da literatura nacional para, por fim, tratar da inovação estética de Lispector (tese principal). Dessa forma, nas premissas da argumentação mobiliza a figura da alusão, citações, a argumentação pela analogia e o argumento de autoridade (caracterizado pela citação). Tais recursos comprovam que Candido é bem-informado e compartilha opiniões de referências no âmbito da crítica, assim, é dotado de credibilidade, tornando seu discurso capaz de conduzir o leitor do jornal a se tornar leitor do romance, característica do gênero epidítico que, ao enaltecer, guia o leitor para a ação.

No exame dos mecanismos retóricos que amplificam Clarice Lispector, os primeiros elogios redundam na inovação proposta pela escritora. Assim, observa-se que o crítico mobilizou os seguintes recursos retóricos: as figuras da metáfora, da alusão e do eufemismo; a argumentação pela regra de justiça; o lugar de qualidade e; a seleção lexical. Convém acrescentar que, quando Candido introduz Clarice Lispector em seu discurso, mobiliza mais recursos retóricos, já que se trata da tese principal na qual o crítico-orador adequa a imagem da escritora ao seu devido valor: desloca-a da literatura corriqueira e a aloca na escrita rara.

Frente à inovação estética, o crítico literário demonstra simpatia com o estilo da autora e tal simpatia é enfatizada por intermédio do lugar de qualidade e de essência, da figura da antítese e da seleção lexical. Assim, ressalta que apesar de referências estrangeiras à obra de estreia, essa se distancia do comum, configurando-se em um romance singular, superior e que representa a essência da literatura no momento. Por fim, analisa-se o aval crítico, no qual é mobilizada apenas a seleção lexical, entretanto, não o faz menos importante na produção do elogio, já que é mediante esse recurso 
retórico que Antonio Candido não só confirma o valor da escritora na literatura nacional, como também avista um futuro sólido para Clarice Lispector.

Com base no exame dos dados, confirmou-se a hipótese inicial de que é possível encontrar recursos retóricos de amplificação que permitem a constituição de um discurso laudatório a respeito da autora. Em caráter de recordação, a amplificação positiva pode ser expressa mediante ao elogio e o discurso laudatório redunda no louvor ou censura. Confirmou-se a hipótese inicial, pois os recursos retóricos mobilizados remetem à superioridade da escritora, de forma que a avalia positivamente, constituindo, portanto, um discurso de louvor. Dessarte, Antonio Candido reconhece o valor de Clarice Lispector e mostra a relevância da inovação apresentada pela escritora, o que torna o discurso um parecer de louvor devido à gama de técnicas argumentativas que configuram o elogio e posiciona a estreante como superior na produção literária do momento. Portanto, a amplificação intensifica a ação de conduzir o leitor do jornal ao romance, qual seja a intencionalidade retórica do crítico-orador.

\section{REFERÊNCIAS}

ABREU, Antônio Suarez. A arte de argumentar: gerenciando razão e emoção. São Paulo: Ateliê Editorial, 2013.

ARISTÓTELES. Retórica. Tradução: Manuel Alexandre Júnior, Paulo F. Alberto e Abel N. Pena. São Paulo: Martins Fontes, 2015.

BORELLI, Olga. Clarice Lispector: esboço para um possível retrato. Rio de Janeiro: Nova Fronteira,1981.

BOSI, Alfredo. História concisa da literatura brasileira. São Paulo: Cultrix, 2015.

CANDIDO, Antônio. Notas de Crítica Literária "Perto do Coração Selvagem", Folha de S. Paulo, 16 jul. $1944 . \quad$ Disponível em: https://acervo.folha.com.br/leitor.do?numero=22939\&anchor $=187498$ \&origem=busca\&pd $=3$ 8b5913f2412ag62780of627484c0936. Acesso em: 10 set. 2020.

CANDIDO, Antônio. Vários escritos. São Paulo: Duas cidades, 2004.

CORREA, Bruna. C. A retórica de Candido na construção das imagens de si e de Clarice. Mandinga, Redenção, v. 4, n. 1, p. 38-55, 2020. Disponível em: http://www.revistas.unilab.edu.br/index.php/mandinga/article/view/429. Acesso em: 13 set. 2020.

FERREIRA, Luiz Antônio. Leitura e persuasão: princípios de análise retórica. São Paulo: Contexto, 2010.

FIORIN, José Luiz. Figuras de Retórica. São Paulo: Contexto, 2019. 
GOTLIB, Nádia. B. Clarice: uma vida que se conta. São Paulo: EDUSP, 2009.

LISPECTOR, Clarice. Perto do coração selvagem. Rio de Janeiro: Rocco, 2019.

MEYER, Michel. Questões de Retórica: linguagem, razão e sedução. Tradução: António Hall. Lisboa: Edições 70, 2007.

MOSCA, Lineide L. Salvador (org.). Retóricas de ontem e de hoje. São Paulo: Humanitas, 2001. PERELMAN, Chaïm; OLBRECHTS-TYTECA, Lucie. Tratado de argumentação: a nova retórica. Tradução: Maria E. A. P. Galvão. 3. ed. São Paulo: Martins Fontes, 2014.

PINTO, Manuel. C. A vocação crítica de Antonio Candido, CULT, 11 mar. 2010. Disponível em: https://revistacult.uol.com.br/home/vocacao-critica-de-antonio-candido/. Acesso em: 10 set. 2020.

REBOUL, Oliver. Introdução à retórica. Tradução: Ivone C. Benedetti. São Paulo: Martins Fontes, 2004.

RODRIGUES, Joana. Antonio Candido e Ángel Rama: Críticos Literários Na Imprensa. São Paulo: Editora Unifesp, 2018.

ROSA, André. S. Clarice Lispector é reconhecida como patrona da literatura de Pernambuco, Diário de Pernambuco, 11 ago. 2020. Disponível em: https://www.diariodepernambuco.com.br/noticia/viver/2020/08/clarice-lispector-ereconhecida-como-patrona-da-literatura-de-pernambu.html. Acesso em: 13 set. 2020.

TRINGALI, Dante. Introdução à retórica: a retórica como crítica literária. São Paulo: Duas cidades, 1988. 